FARKAS TAMÁS - SLÍZ MARIANN szerk., Tulajdonnevek és szótárak. ELTE Magyar Nyelvtudományi és Finnugor Intézet - Magyar Nyelvtudományi Társaság,

Budapest, 2020. 199-207. DOI: 10.26546/4892373.12

\title{
Magyar tulajdonnevek a cseh és szlovák névszótárakban"
}

1. Bevezetés. A tanulmány arra a kérdésre keresi a választ, hogy a cseh és szlovák névszótárakban szerepelnek-e magyar tulajdonnevek, és ha igen, miként magyarázzák őket; használnak-e magyar szakirodalmat; van-e tendenciaszerüség és időbeli változás a magyarázatokban. Csak azokat a névszótárakat, illetve névszótári részeket tartalmazó publikációkat tárgyaljuk, melyekben találhatók magyar tulajdonnevekkel kapcsolatos névcikkek, névmagyarázatok. Elöbb a magyar tulajdonneveket is tárgyaló cseh és szlovák keresztnév-, majd családnév-, végül pedig helynévszótárakat tekintjük át.

2. Keresztnévszótárak. A legismertebb cseh keresztnévszótárat MiLOSLAVA KNAPPOVÁ írta, a kiadvány a Jak se bude vaše dítě jmenovat? [Hogy hívják majd az Ön gyermekét?] címet viseli. A könyv első kiadása 1978-ban, legutóbbi, átdolgozott és bővített hatodik kiadása 2017-ben jelent meg, s mintegy 17000 keresztnevet tartalmaz (KNAPPOVÁ 2017). Csehországban egy olyan keresztnév bejegyzése érdekében, amely nem található meg az említett névkönyvben, a kérvényezők a Cseh Tudományos Akadémia Nyelvtudományi Intézetének Névtani Osztályához fordulhatnak, ahol szakvélemények készülnek a nevekről.

KNAPPOVÁ (2017) a kiadványban a keresztnevekkel összefüggő általános kérdésekkel is aprólékosan foglalkozik. A szótári részt megelőzően ír a keresztnevek történetéről, a névadást motiváló tényezőkről, a nevek anyakönyvezéséről, a kettős keresztnévadás lehetőségéről, a névválasztással kapcsolatos ajánlásokról, a névdivat változásáról és a névnapokról.

A szótári részben az egyes névcikkekben magyarból átvett keresztnevek is szerepelnek címszóként: a férfinevek közül az Ákos, Aladár, Alajos, Antal, Arpád, Atila, Bálint, Béla, Csaba, Farkas, Ferenc, Gál, Imre, István, Kálmán, Kelemen, Lajos, László, Levente, Lóránt, Nándor, Ödön, Pál, Sándor, Śándor, Tivadar, Vidor, Zoltán, Zsolt; a nöi nevek közül az Aranka, Boglárka, Csilla, Dalma, Enikö, Erzsébet, Hajnal, Hajnalka, Iboja, Ila, Ildika, Ilona, Margit, Marika, Mirtill, Orsolya, Piroska, Réka, Sarolta, Timea, Tünde. A keresztnévszótárban található magyar névcikkek megírásához alapvető forrásul a LADÓ JÁNOS és BíRÓ ÁGNES által kiadott Magyar utónévkönyv szolgált (MUnk. 1998). Egyes névalakok azonban az adott keresztnév cseh nyelvbe való adaptációjáról, névcsehesítésről árulkodnak: Arpád, Atila, Šándor, Iboja, Ildika, Timea. A szótár névcikkeiben KNAPPOVÁ többnyire feltünteti a név eredetét és jelentését, becéző alakváltozatait, idegen nyelvekben szereplő megfelelőit, előfordulásának gyakoriságát és a névnap időpontját. A címszóként álló, magyarból átvett keresztnevek mellett a rövidebb névcikkekben gyakran csak a név eredetét és - ha létezik - cseh megfelelöjét találjuk. A bővebb névcikkekben megfigyelhető a keresztnevekből alkotott becenevek cseh nyelvben való használata is: Antal-Antek, Antalek; Arpád-Arpa, Arpouš(ek), Arp(ád)ek; Atila-Ata,

\footnotetext{
*A tanulmány a Tempus Közalapítvány államközi ösztöndíjának támogatásával készült.
} 
Atík, Atilek; Gál-Galek, Galouš(ek), Galo; Vidor-Vid(ek), Vidorek, Dorek; ZoltánZoltánek, Zolek, Zoli, Tan(ek); Aranka - Arana, Arka, Arin(k)a, Aruška; Dalma - Dalka, Dalmuška, Dalmička; Iboja - Boj(k)a, Ibojka, Ibuš(ka); Ildika - Ilka, Ilda, Ildička, Ildin(k)a, Ildun(k)a; Ilona - Ila, Ilka, Ilča, Ilun(k)a, Iluš(ka), Ilonka; Margit-Margitka, Gita, Gitka, Gituš(ka), Marga, Margo(t); Marika - Marička, Marka, Márinka, Mara, Mája, Májina, Maruna, Majčinka; Timea - Timka, Timča, Timuš(ka), Timečka.

A szlovák keresztnévszótár, melyet a szlovákiai anyakönyvi hivatalokban is használtak, illetve használnak, a MILAN MAJTÁN és MATEJ POVAŽAJ szerzőpárostól származik. A névszótár első kiadása 1983-ban látott napvilágot, a bővített változata pedig 1998-ban, Vyberte si meno pre svoje diet'a [Válasszon keresztnevet gyermekének] címen (MAJTÁN-POVAŽAJ 1998). A szótárban az egyes keresztnevek betürendben találhatók. A keresztnevek mellett rövidítések jelölik a női vagy férfinevet. A névcikkekben a keresztnév eredete és jelentése után a különböző nyelvekben (angol, cseh, francia, magyar, német, olasz, orosz, spanyol, svéd stb.) meglévő névmegfelelők, valamint a keresztnévből származó családnevek szerepelnek. A szótárban a betürendes névlistában fel van tüntetve az összes névváltozat, amely visszakereshető az utaló névcikk alapján; pl. Zsaklin p. Žakelína (p. = pozri 'lásd'), Zsanett p. Žaneta, Zseni p. Eugénia, Zseraldina p. Geraldína, Zsigmond p. Žigmund, Zsófia p. Žofia, Zsóka p. Alžbeta, Zsuzsa p. Zuzana, Zsuzsanna p. Zuzana. A szerzők a magyar névmegfelelők megadásakor LADÓ JÁNOS Magyar utónévkönyv címü kiadványára támaszkodtak (MUnk. 1972).

A szótári részen túl a könyvben olvashatunk a személynevek történetéröl, a kereszténység felvétele előtt használatos régi szláv nevekről, a keresztségben kapott személynevekröl, a keresztnévi eredetü családnevekröl, a névdivatról, a keresztnevek anyakönyvezéséről, a hármas keresztnévadás lehetőségéről, az új keresztnevek létrejöttéről, a névválasztásról és -változtatásról, a női családnevek használatáról, az egyes nevek névnapjának időpontjáról, a keresztnevek becenévi alakváltozatairól. Az 1998-ban megjelent szótár óta nagyban változott a keresztnévdivat, bővült a névállomány Szlovákiában, ezért szükség lenne az említett névszótár bővített kiadására. Tudomásom szerint nincs tervben a könyv újabb kiadása. A szlovákiai anyakönyvi hivatalokban egyéb online névforrásokat használnak: minden olyan keresztnevet bejegyeznek az anyakönyvbe, mely megtalálható bizonyos nemzetközi weboldalak valamelyikén. ${ }^{1}$ Egy újonnan kérvényezett keresztnév bejegyzésével kapcsolatban csak ritkán fordulnak a Szlovák Tudományos Akadémiához tanácsadásért, és szakvélemények sem készülnek a nevekröl. Ez annak is köszönhetö, hogy a vonatkozó törvényekben nincs ezzel kapcsolatos meghatározás, és az anyakönyvvezetők online keresztnévjegyzékeket is használnak, melyek bőséges névadatbázist nyújtanak ugyan, de téves névformákat is tartalmazhatnak.

3. Családnévszótárak. MiloslaVA KNAPPOVÁ Naše a cizí př́ijmení v současné češtině [A mai cseh nyelvben lévő hazai és idegen családnevek] címü családnévkönyve 1992-ben, majd bővített kiadása 2008-ban jelent meg. Nem klasszikus családnévszótárról van szó, a szerző a családneveket általában szövegkörnyezetben tárgyalja, de bizonyos fejezetekben névcikkek is elöfordulnak. A könyv végén található névmutató megkönnyíti az egyes családnevek visszakeresését. A kiadvány a következő fejezetekből áll: a cseh családnevek története, a cseh családnevek eredete és jelentése, a családnevek

1 A használatos weboldalak: www.babynames.com, www.babynameworld.com, www. babynology.com. (2020. 04. 24.) 
alaktani sajátosságai, az idegen (női) családnevek adaptációja a cseh nyelvbe, a családnevek helyesírási sajátosságai, a családnevek átírása egyes idegen nyelvekből, családnévváltoztatások, nemesi családnevek, a családnevek gyakorisága (KNAPPOVÁ 2008).

A szerző a magyar eredetű családnevek értelmezésekor KÁZMÉR MIKLÓs Régi magyar családnevek szótára címü müvére (CsnSz.) támaszkodik. KNAPPOVÁ a magyar családnevek helyesírásával, kiejtésével, a cseh nyelvben való toldalékolásával kapcsolatban is megjegyzéseket tesz. A magyar tulajdonnevek cseh nyelvben megfigyelhetö helytelen kiejtése a két nyelvben előforduló eltérő fonémákkal függ össze. A szerző megemlíti a családnevek helyesírása és cseh nyelvbeli kiejtése közötti különbségeket, genitívuszi alakváltozatát és a női nevekhez kapcsolódó -ová névformánst; pl. Balázs [baláž], -zse - Balázsová [balážová]; Juhász [juhás], -sze - Juhászová [juhásová]; Jankovics [jankovič], -cse - Jankovicsová [jankovičová]. Felhívja a figyelmet továbbá arra is, hogy a kisebbségi nők elhagyhatják a családnév végéről az -ová képzőt: Aranyová [araňová] és Arany [araň]; Nagyová [nad'ová] és Nagy [nad']; Királyová [kirájová] és Király [kiráj]. A kettős családneveknél többféle alakváltozattal is találkozhatunk a nöknél; pl. Dudásová-Vigová, Dudás-Vigová, Dudás-Vig. A magyar családnevek adaptációja a cseh nyelvbe a család- és keresztnév eltérö névsorrendjében, valamint a névforma variábilis használatában is mutatkozik: Kovács Pálné Szabó Katalin $\rightarrow$ Katalin Kovácsová Szabóová (Szabó), Katalin Kovácsová rozená ('született') Szabóová (Szabó); Kovácsné Szabó Katalin $\rightarrow$ Katalin Kovácsová Szabóová (Szabó); Kovácsné Sz. Katalin $\rightarrow$ Katalin Kovácsová, Katalin Sz. Kovácsová; K. Szabó Katalin $\rightarrow$ Katalin K. Szabóová; Kovács Katalin $\rightarrow$ Katalin Kovácsová. A magyar családnevek csehesítését példákkal szemlélteti KNAPPOVÁ: Bárczi - Bárci, Csillag - Čillag, Gergely - Gergej, Kiss - Kǐ̌̌š, Nagy - Nad, Nyíri - Níri, Szatmári - Satmári, Tyúk - Ťúk, Zsolt-Žolt.

MILAN MAJTÁN szlovákiai családnevekről írott, Naše priezviská [Családneveink] című monográfiája 2014-ben jelent meg. A kiadványban névcikkek is találhatók, de a cseh családnévkönyvhöz hasonlóan többnyire a szövegben előforduló felsorolások, adatolások részeként szerepelnek az egyes családnevek. A szerző az első fejezetben a szlovák családnevek kialakulásával, nyelvi eredetével és formájával, gyakoriságával foglalkozik. A második részben a családnévadás indítékairól, a nevek képzésmódjairól olvashatunk. Az egyes családnevek etimológiáját és a köztük lévő összefüggéseket a legterjedelmesebb fejezet tárgyalja, amelyben a következő kérdéseket érinti a szerző: a névadás indítéka, a név nyelvi eredete, müvelödéstörténeti vonatkozásai, történeti forrásokban való megjelenése, területi és számbeli előfordulása, alakváltozatai, idegen nyelvü megfelelői, a névalkotás módja és a nyelvjárások hatása a családnév keletkezésében. A negyedik részben turzófalvai családnevek magyarázata található rövid névcikkek formájában (bövebben 1. MAJTÁN 2011). Az ötödik fejezet a családnévkutatás és a genealógia közötti összefüggésekről számol be. A könyv végén lévő névmutató segíti a névvel kapcsolatos információk keresését (MAJTÁN 2014).

Nagy számban jelennek meg a kötetben magyar nyelvből származó családnevek. Az 1995-ös szlovákiai lakosság-nyilvántartás alapján a Szlovákiában használatos leggyakoribb családnevek között is szerepelnek magyar eredetüek, melyek többsége különféle alakváltozatban fordul elö: Kováč (-áč 15238, -ač 125, -ács 4832, -acs 25), Horváth (-áth 15092, -át 1269, -ath 285, -at 1539), Varga (11699), Tóth (11419), Szabó (Szabó 6818, Szabo 1585, Sabó 395), Nagy (10315) / Nad' (433), Baláž (-áž 7351, -áš 21, -ázs 860, -azs 80), Molnár (-ár 6714, -ar 6), Lukáč (-áč 5132, -ač 134, -ács 740, -acs 49). Egyes családnevek e példasorból szláv családnévadás eredményei is lehetnek. A magyar 
családnevek interpretációjakor HAJDÚ MIHÁLY Családnevek enciklopédiája címü munkáját (CsnE.) vette alapul MAJTÁN. A szerző a névadás indítéka szerint csoportosítja a névanyagot, s magyarból átvett példákat is említ könyvében. Magyar keresztnévalakból származó családnevek: Miklós > Mikla, Mikl’a, Mikle, Miklánek, Mikláš, Miklo, Mikloš, Miklošik, Mikloško, Miklošovič, Miklovič stb.; magyar foglalkozásnevekből származó családnevek: Áč, Barát, Bíro, Doboš, Fazekaš, Kadár, Lakatoš, Lovás, Madarás, Mesároš, Molnár, Sabo, Sakáč, Sekerě̌, Šipoš, Takáč, Vámoš, Varga, Žoldoš stb.; magyar helynévböl alakult családnevek: Arvai, Bartfai, Budaj, Gömöri, Honti, Kaššai, Lévai, Liptai, Nyitrai, Sepeši, Šároši, Turóci, Zólyomi, Žolnai stb.; a népnév magyar megnevezéséből alakult családnevek: Horvát, Lendel, Lengyel, Morvai, Német, Oláh, Oros, Rác, Tót, Török stb.; tulajdonságra utaló ragadványnévböl származó magyar eredetü családnevek: Farkaš, Igaz, Pirošik, Rigo, Sarka, Szarka, Varju, Veréb, Vereš stb. A családnevek lejegyzésében megfigyelhető, hogy a magyar eredetü családnevek java része a névszlovákosítás eredményeképpen szlovákos helyesírással fordul elő.

DANIEL DUDOK Priezviská Slovákov v Juhoslávii [A szlovákok családnevei Jugoszláviában] címü, 1998-ban megjelent könyvében szintén nagyobb számban találkozhatunk magyar családnevekkel. Ez sem hagyományos családnévszótár, a következő főbb részekből áll: a személynevek története, szlovák családnevek és szlovákok által viselt családnevek, a vajdasági és szlovákiai szlovákok családnevei, a vajdasági szlovákok családneveinek lexikális-szemantikai elemzése. A névmutató segíti a családnevek fellelhetőségét a könyvben. A szerző a legterjedelmesebb fejezetben lexikális-szemantikai szempontból osztályozza és névcikkek formájában közli a korpuszt (több mint 4200 családnevet). Az egykori Jugoszláviában élő szlovákok családneveiben a névszlovákosítás a magyar eredetủ családnevek helyesírásában figyelhető meg; pl. Andráš, Baláž, Birkášs, Bizoň, Bordáš, Búzáš, Čásár, Čordáš, Déně̌, Derd' (< György), Doboš, Farkaš, Frideš, Híreš, Ištók, Ištván, Kálman, Láslo, Madarás, Mesároš, Mihál', Nad', Ol’ajoš, Pálinkáš, Sakáč, Sakáloš, Šándor, Tamaši, Vašaš, Vereš, Vilmoš, Žíroš. Az etnikumra utaló Magyar családnév különféle alakváltozatokban fordul elő: Mad'ar, Mad'ara, Mad'arek, Mad'arik. DuDOK a magyar névtani szakirodalomból KNIEZSA ISTVÁN A magyar és szlovák családnevek rendszere (1965) címủ munkáját használta az egyes családnevek etimologizálásakor.

Szótárszerű részek, magyar családnevek magyarázatai is találhatók a magyarországi szlovákok családneveit feldolgozó Čabianske priezviská [Békéscsabai családnevek] és Komlóšske priezviská [Tótkomlósi családnevek] címü kiadványokban (DIVIČANOVÁ et al. 2015, 2017).

4. Helynévszótárak. Nem hagyományos helynévszótár, de szótárszerü részeket, névcikkeket, magyar tulajdonneveket is tartalmaz a cseh VLADIMÍR ŠMILAUER Vodopis starého Slovenska [A régi Szlovákia vízrajza] címü, 1932-ben megjelent munkája, mely behatóan elemzi a szláv, magyar és más eredetü vízneveket. A szerző jól ismeri és szakszerüen használja a korabeli magyar szakirodalmat és a középkori magyarországi okleveleket. A mü bevezető részében ismerteti a történeti forrásokat (1300-ig vizsgálja a névanyagot), a kutatás módszereit és a munka szerkezetét (ix-xliii). Az egyes folyók (Morva, Duna, Dudvág, Vág, Nyitra, Garam, Ipoly, Sajó, Hernád, Bodrog, Poprád) szerint haladva mutatja be a vízneveket. Az adattárban közli a víznevek etimológiai magyarázatát. Az összegyüjtött korpuszt a névadás indítéka szerint rendszerezi: köznévi, személy- és helynévi, ismeretlen és bizonytalan eredetü vízneveket különböztet meg. A magyar eredetű köznévből származó víznevek mellett feltünteti cseh megfelelöjüket, 
jelentésüket, továbbá a történeti forrásokban előforduló magyar névalakokat, melyekben az adott névrész megtalálható. A magyar személy- és helynévből keletkezett vízneveknél szerepel az adott névrész írott forrásokban való előfordulása és a név keletkezésmagyarázata. A könyv befejező részében a történeti forrásokban szereplö nevek magyar nyelvü lejegyzésének sajátosságairól olvashatunk, majd a források értékelése és a nevek jegyzéke következik (ŠMILAUER 1932).

Az utóbbi években újra fellendült a víznevek kutatása, melyet egykor ŠMILAUER kezdeményezett. 2005-ben jelent meg JAROMÍR KRŠKO Spracovanie hydronymie Slovenska [Szlovákia vízneveinek feldolgozása] címü monográfiája, melyben módszertani útmutatót ad a Hydronymia Slovaciae nevezetü projekt keretén belül készülő tanulmányok elkészítéséhez (KRŠKO 2005). Önálló kötetekben a következö folyók vízneveit dolgozták fel a szlovák névtanosok: a Sajó szlovákiai része (SIČÁKOVÁ 1996), Ipoly (MAJTÁN-ŽIGO 1999), Túróc (KRŠKO 2003), Nyitra (HLADKÝ 2004), Árva (MAJTÁN-RYMUT 2006), Garam (KRŠKO 2008), a Vág felső része (KRŠKO 2011), Kiszuca (KRŠKO-VELIČKA 2011), Dudvág (HLADKÝ 2011), a Morva (ZÁVODNÝ 2012) és a Hernád folyók szlovákiai része (GoÓTŠOVÁ-CHOMOVÁ-KRŠKo 2014), Kis-Duna (BELÁKOVÁ 2014, BELÁKOVÁHLADKÝ-ZÁvODNÝ 2018), valamint a Csallóköz víznevei (HLADKÝ-ZÁvODNÝ 2015). A hidronimákat feldolgozó szlovák kiadványokban szótári rész is található, melynek névcikkeiben a címnév után következik az adott helynév pontos lokalizálása, a történeti forrásokban szereplő névalakváltozatok felsorolása, a víznév etimológiájának magyarázata. Az említett kötetekben gyakran találkozhatunk magyar eredetü víznevekkel. A magyar névtani munkák közül a legidézettebb KIsS LAJOS kétkötetes, Földrajzi nevek etimológiai szótára címủ müve (FNESz.).

Magyar településneveket is tárgyaló szlovák helységnévszótár JÁN STANISLAV 1947-ben megjelent, Odkryté mená slovenských miest a dedín [Szlovák városok és falvak feltárt nevei] címü könyve, melyet 2008-ban újranyomtattak. A névcikkekben a címnévként álló helységnév után következik a település lokalizálása, a történeti forrásokban lévő névváltozatok ismertetése, s végül az adott név keletkezésmagyarázata. Egyes névcikkekben a szlovák helységnév magyar névpárjáról (pl. Eperjes, Pozsony, Kassa) bővebb névmagyarázatot olvashatunk (STANISLAV 1947).

Hasonló szerkezetben szerepelnek a névcikkek JÁN STANISLAV 1948-ban kiadott, majd 1999-ben (1. kötet) és 2004-ben (2. kötet) újranyomott Slovenský juh v stredoveku [A szlovák dél a középkorban] címü terjedelmes kétkötetes könyvének második, szótári részében. E névtárban nemcsak helységnevek, hanem egyéb helynévfajták (pl. víznevek, domborzati nevek) etimológiája is megtalálható. A szerző gyakran idézi monográfiájában KNIEZSA ISTVÁN, MELICH JÁNOS és MoÓR ElEMÉR tanulmányait. Az irodalomjegyzék azt mutatja, hogy jól ismerte a korabeli magyar munkákat, forrásokat, nyelvészeti folyóiratokat. A helynévszótár több ezer helynév etimológiáját tartalmazza. STANISLAV számos magyar eredetủ nevet tendenciaszerủen a szlávból magyaráz. Az idők során a névkutatók sok, általa helytelenül etimologizált nevet újraértelmeztek, de számos, elsősorban nem magyar eredetủ helynevekkel kapcsolatos megállapítását elfogadták. A kiadvány második részére gyakran hivatkozik KISS LAJOS a FNESz. egyes névcikkeiben, cáfolva STANISLAV magyar eredetủ helynevekkel kapcsolatos helytelen etimologizálásait.

A cseh helynévszótárakban csak ritkán találkozhatunk magyar nevek magyarázataival, a szláv eredetủ nevek mellett német etimonúak jelennek meg nagy számban a vonatkozó kiadványokban (1. PROFOUS 1947-1960, HOSÁK-ŠRÁMEK 1970-1980, LUTTERER-ŠRÁMEK 2004). Az IVAN LUTTERER, LUUBOŠ KROPÁČEK és VÁCLAV HUŇÁČEK 
szerzőhármas által írt Původ zeměpisných jmen. Etymologický slovník 1000 vlastních jmen zemí, měst a př́rodních objektů [Helynevek eredete. 1000 tulajdonnév - országnév, településnév, természeti objektum - etimológiai szótára] címü, 1976-ban kiadott cseh nyelvü helynévszótár magyar helyneveket is etimologizál. A helynévfajták közül városnevek (Budapest, Debrecen, Esztergom, Györ, Pécs, Szeged, Székesfehérvár, Szolnok, Sopron, Veszprém) és egy-egy folyónév (Tisza), hegynév (Kékes), országnév (Magyarország) eredetmagyarázata fordul elő a publikációban. A magyar névtani irodalomból KÁLMÁN BÉLA A nevek világa címü könyvét (1967) használták a szerzők (LUTTERERKROPÁČEK-HUŇÁČEK 1976).

Az IVAN LUTTERER, MiLAN MAJTÁN és RUdOLF ŠRÁMEK által írt Zeměpisná jména Československa [Csehszlovákia földrajzi nevei] címü 1982-es kiadványban mintegy 1200 helynév (helységnév, hegynév, víznév) etimológiája szerepel névcikkek formájában. Egyes, Szlovákia területén lévő helynevek eredetmagyarázatánál a magyar névpárok (pl. Bártfa, Nagyszombat, Somorja, Tornalja) etimológiája is megtalálható.

A szlovákiai helységnevek jegyzékét és az egyes toponimák 1773-1997 közötti névváltozatait tartalmazza MILAN MAJTÁN több kiadásban megjelent Názvy obcí Slovenskej republiky. Vývin v rokoch 1773-1997 [A Szlovák Köztársaság helységnevei. Változásuk az 1773-1997 közötti években] címü könyve (MAJTÁN 1998). A bevezetőt követi a szótári rész, melyben 2871 névcikk szerepel; ${ }^{2}$ az egyes helységnevek mellett időrendi sorrendben szerepelnek a történeti forrásokban előforduló névalakváltozatok. Az adatok a társadalmi változások névanyagra való hatását, a szlovák-magyar helységnévpárok alakulását és a lejegyzett magyar alakváltozatok variabilitását is mutatják (pl. Hurbanovo - 1773, 1786 O-Gyalla, 1808 Ó-Gyálla, 1863-1913, 1938-1945 Ógyalla, 1920-1938, 1945-1948 Ó-Gyalla). A betürendes névmutatóban az összes névváltozat listája található.

MILAN MAJTÁN irányításával valósult meg 1966-1975 között egy egész Szlovákiára kiterjedő, helyneveket összegyüjtő kérdőíves kutatás, melynek eredményeképpen mintegy 250000 mikrotoponima gyült össze (1. MAJTÁN 1983). Ezen névkorpusz feldolgozása napjainkban a Szlovák Tudományos Akadémia Nyelvtudományi Intézetében zajlik. IVETA VALENTOVÁ, a Névtani Osztály vezetője dolgozik a digitális helynévtáron. Egyelöre az ábécé első betüjéhez tartozó mintegy 2000 helynév feldolgozása készült el a Slovník lexiky slovenských terénnych názvov [A szlovák mikrotoponimák lexikájának szótára] című projekt keretén belül (1. VALENTOVÁ 2009, 2014, 2018; LSTN.). A helynévanyag feldolgozása a cseh és morva mikrotoponimák digitális helynévtárához hasonló módon történik (1. ČIŽMÁROVÁ 2010a, 2010b; OLIVOVÁ-NEZBEDOVÁMALENÍNSKÁ 2000; SPJČ.; SPJMS.). A szlovák digitális helynévtár névcikkeiben szlovák nyelvbe adaptált magyar eredetü helynevekkel (pl. Ajandéky < ajándék, Ad’agaš < agyagos, Almáš < almás, Pod álomášom < állomás), illetve ezek lokalizálásával, etimologizálásával, toldalékolásával, digitális térképre vetítésével is találkozhatunk.

5. Összegzés. A cseh és szlovák keresztnév-, családnév- és helynévszótárakban, illetve névszótári részeket tartalmazó publikációkban található magyar tulajdonnevekkel kapcsolatos névcikkek, névmagyarázatok azt mutatják, hogy az említett cseh és szlovák névtani lexikográfiai munkák többsége elfogadhatóan interpretálja a magyar tulajdonneveket, és hivatkozik - ha viszonylag kis mértékben is - a magyar szakirodalomra is. Egyes magyar

${ }^{2}$ Az egyes településekhez kapcsolódó névcikkeket 1. http://www.juls.savba.sk/nazvy_bci.html. (2020. 04. 24.) 
eredetü tulajdonnevek lejegyzésében megfigyelhető, hogy a név adott nyelvbe való adaptációja a névcsehesítés, illetve névszlovákosítás eredményeképpen csehes, illetve szlovákos helyesírással használatos. A cseh és szlovák névszótárak fontos forrásként szolgálnak a szláv eredetű tulajdonnevek magyarázatát illetően is a magyar névkutatók számára.

\section{Felhasznált források}

BelÁKovÁ, MÁRIA 2014. Hydronymia severnej časti povodia Malého Dunaja. Trnavská univerzita, Trnava.

BelákovÁ, MÁria - HLAdKÝ, Juraj - ZÁvodnÝ, Andrej 2018. Hydronymia Malého Dunaja. Trnavská univerzita, Trnava.

DiviČANOvÁ, ANNA et al. 2015. Čabianske priezviská. Výskumný ústav Slovákov v Mad’arsku, Békešská Čaba.

DiviČANOVÁ, ANNA et al. 2017. Komlóšske priezviská. Vydavatel'stvo Ivan Krasko, Nadlak.

DudoK, DANIEL 1998. Priezviská Slovákov v Juhoslávii. Spolok vojvodinských slovakistov, Nový Sad.

GOÓTŠOVÁ, ANDREA - CHOMOVÁ, ALEXANDRA - KRŠKO, JAROMÍR 2014. Hydronymia slovenskej časti povodia Hornádu. Belianum, Banská Bystrica.

HLAdKÝ, JuRAJ 2004. Hydronymia povodia Nitry. Pedagogická fakulta Trnavskej univerzity, Trnava.

HLADKÝ, JuRAJ 2011. Hydronymia povodia Dudváhu. Pedagogická fakulta Trnavskej univerzity, Trnava.

HLAdKÝ, JuRAJ - ZÁvodnÝ, ANDReJ 2015. Hydronymia Žitného ostrova. Pedagogická fakulta Trnavskej univerzity, Trnava.

HosÁK, LAdislaV - ŠRÁMEK, Rudolf 1970-1980. Místní jména na Moravě a ve Slezsku 1-2. Academia, nakladatelství Československé akademie vied, Praha.

KNAPPOVÁ, Miloslava 1978/2017. Jak se bude vaše dítě jmenovat? Academia, Praha.

KNAPPOVÁ, MiloslaVA 1992/2008. Naše a cizi přijmení v současné češtině. AZ KORT, Liberec.

KRŠKO, JAROMÍR 2003. Hydronymia povodia Turca. Univerzita Mateja Bela, Fakulta humanitných vied, Banská Bystrica.

KRŠKO, JAROMÍR 2008. Hydronymia povodia Hrona. Univerzita Mateja Bela, Banská Bystrica.

KRŠKO, JAROMÍR 2011. Hydronymia horného povodia Váhu (od povodia Rajčianky po pramen̆ Váhu). Univerzita Mateja Bela, Banská Bystrica.

KRŠKO, JAROMÍR - VELIČKA, DRAHOMÍR 2011. Hydronymia povodia Kysuce. Univerzita Mateja Bela, Banská Bystrica.

LSTN. = Lexika slovenských terénnych názvov. https://lstn.juls.savba.sk (2020. 04. 24.)

LUTTERER, IVAN - KROPÁČEK, L'UBOŠ - HuŇÁČEK, VÁCLAV 1976. Původ zemépisných jmen. Etymologický slovník 1000 vlastnich jmen zemí, měst a př́rodnich objektů. Mladá fronta, Praha.

LUTTERER, IVAN - MAJTÁN, MILAN - ŠRÁMEK, RUdOLF 1982. Zeměpisná jména Československa. Mladá fronta, Praha.

LUTTERER, IVAN - ŠRÁMEK, RUDOLF 2004. Zeměpisná jména v Čechách, na Moravě a ve Slezsku. Slovník vybraných zemépisných jmen s výkladem jejich původu a historického vývoje. 2. vydání. Tobiáš, Havlíčkův Brod.

MaJTÁN, MiLAN 1972/1998. Názvy obci Slovenskej republiky (Vývin v rokoch 1773-1997). Veda, Bratislava. 
MaJTÁn, Milan 2011. Slovník turzovských priezvisk. In: GaJdIČIAR, IvAN ed., Turzovské priezviská. Spolok priatel'ov Turzovky, Turzovka. 75-211.

Majtán, Milan 2014. Naše priezviská. Veda, vydavatel'stvo Slovenskej akadémie vied, Bratislava.

MaJTÁn, Milan - PovažAJ, MATEJ 1983/1998. Vyberte si meno pre svoje dieta. Art Area, Bratislava.

MAJTÁn, MiLAN - RYMUt, KAZIMIERZ 2006. Hydronymia povodia Oravy. Veda, Bratislava.

MaJTÁN, Milan - ŽIgo, PAVOL 1999. Hydronymia povodia Ipla. Jazykovedný ústav Luudovíta Štúra SAV, Bratislava.

OLIVOVÁ-NEZBEDOVÁ, LIBUŠE - MALENÍNSKÁ, JiTKA 2000. Slovník pomistních jmen v Čechách. Úvodni svazek. Academia, Praha.

PROFOUS, ANTONín 1947-1960. Místní jména v Čechách. Jejich vznik, pưvodní význam a změny 1-5. Nakladatelství ČSAV, Praha.

SiČÁKOVÁ, ĹUBA 1996. Hydronymia slovenskej časti povodia Slanej. Pedagogická fakulta UPJŠ, Prešov.

ŠMilauer, Vladimír 1932. Vodopis starého Slovenska. Učená společnost Šafaříkova, PrahaBratislava.

SPJČ. $=$ Slovnik pomistnich jmen $v$ Čechách. https://spjc.ujc.cas.cz (2020. 04. 24.)

SPJMS. = Slovník pomístních jmen na Moravě a ve Slezsku. https://spjms.ujc.cas.cz (2020. 04. 24.)

STANISLAV, JÁN 1947/2008. Odkryté mená slovenských miest a dedín. Vydavatel'stvo Matice slovenskej, Martin.

STANISLAV, JÁN 1948/1999/2004. Slovenský juh v stredoveku 1-2. Národné literárne centrum, Bratislava.

VAlENTOVÁ, IVETA 2018. Lexika slovenských terénnych názvov (Koncepcia lexikografického spracovania). Slovak Academic Press, Bratislava.

ZÁvOdNÝ, ANDREJ 2012. Hydronymia slovenskej časti povodia Moravy. Pedagogická fakulta Trnavskej univerzity, Trnava.

\section{Hivatkozott irodalom}

ČIŽMÁROVÁ, LIBUŠE 2010a. Tvorba elektronického slovníku pomístnich jmen na Moravě a ve Slezsku. Acta onomastica 51: 79-93.

ČIŽMÁROVÁ, LiBUŠE 2010b. Ke konstrukci heslových slov ve Slovníku pomístních jmen na Moravě a ve Slezsku. Acta onomastica 51: 94-105.

CsnE. = HAJdú MıHÁLY, Családnevek enciklopédiája. Leggyakoribb mai családneveink. A magyar nyelv kézikönyvei 17. Tinta Könyvkiadó, Budapest, 2010.

CsnSz. = KÁzMÉR MIKLós, Régi magyar családnevek szótára XIV-XVII. század. Magyar Nyelvtudományi Társaság, Budapest, 1993.

FNESz. = KISS LAJOS, Földrajzi nevek etimológiai szótára 1-2. 4., bővített és javított kiadás. Akadémiai Kiadó, Budapest, 1988.

KÁLMÁN BÉLA 1967. A nevek világa. Gondolat Kiadó, Budapest.

KNIEZSA IsTVÁn 1965. A magyar és szlovák családnevek rendszere. Sokszorosított gépirat. Budapest.

KRŠKO, JAROMÍR 2005. Spracovanie hydronymie Slovenska (Metodické pokyny na spracúvanie projektov Hydronymie Slovaciae). Univerzita Mateja Bela, Fakulta humanitných vied, Banská Bystrica. 
MaJTÁN, MiLAN 1983. Slovníkovo-areálové spracovanie lexiky slovenských terénnych názvov. Slovenská reč 48: 199-206.

MUnk. 1972 = LADÓ JÁNOS, Magyar utónévkönyv. 2. kiadás. Akadémiai Kiadó, Budapest, 1972. MUnk. 1998 = LADÓ JÁNOS - Bíró ÁGNES, Magyar utónévkönyv. Vince Kiadó, Budapest, 1998.

VALENTOVÁ, IVETA 2009. Ku koncepcii pripravovaného Slovníka slovenských anojkoným. Slovenská reč 74: 283-291.

VALENTOVÁ, IVETA 2014. Výstavba heslových slov slovníka lexiky slovenských terénnych názvov. In: ONDREJOVIČ, SLAVOMíR - SATINSKÁ, LUCIA - VRÁBL’OVÁ, JÚliA szerk., Śtefan Peciar a moderná lexikografia. Zborník k 100. výročiu narodenia Štefana Peciara. Veda, vydavatel'stvo Slovenskej akadémie vied, Bratislava. 280-296.

BAUKO JÁNOS

ORCID: https://orcid.org/0000-0003-1297-6177

Nyitrai Konstantin Filozófus Egyetem

Közép-európai Tanulmányok Kara

\section{JÁNOS BAUKO, Hungarian proper names in Czech and Slovakian name dictionaries}

The study aims to discern whether Czech and Slovakian name dictionaries list Hungarian proper names, and if yes, how these are defined; is Hungarian scholarly literature referenced; can any tendencies or changes over time be found in their definitions. Only name dictionaries and publications that include name dictionaries that contain entries for Hungarian proper names are discussed. First, the Czech and Slovakian given name dictionaries, then family name dictionaries that contain Hungarian proper names are discussed. Finally, dictionaries of toponyms are also reviewed. The majority of Czech and Slovakian name dictionaries or publications that contain such elements define Hungarian proper names acceptably, and (to a minor degree) reference Hungarian academic literature. The adaptation of the orthography of specific Hungarian proper names can be seen in some cases. As a result, Slovakian or Czech name forms are in use. Czech and Slovakian name dictionaries are also an essential source of information regarding names of Slavic origin in the Hungarian language for Hungarian onomasticians. 